\title{
Pravidla vztahující se na činnost veřejného ochránce práv a kritéria uplatnitelná na užití jeho volné úvahy
}

\author{
Rules of Conduct of the Public Defender of Rights \\ and the Criteria Applicable to Their Discretion
}

\author{
Anna Chamráthová*
}

\begin{abstract}
Abstrakt
Clánek se zabývá tím, zda lze na činnost verejnébo ochránce práv, instituce z.povaby véci a ze zásady nesvázané procesnimi predpisy, vątáhnout i jiná pravidla a kritéria než ta zákonná. Zaměruje se predevšim na to, jak tato kritéria mohou limitovat uřiti volné úvahy ochránce. V prvni ćásti článek proto popisuje, ve keterých prípadech činnosti ochránce a do jaké míry se jedná o užití jeho volného uvážení. Hlavni ćást textu je poté zamèrena na podrobnou analýzu, jaká pravidla a kritéria by se na činnost ochránce a ư̌iváni jeho volné úvaby potenciálnè mobla vžtahovat. Následnè se článek zabývá tím, na které prípady užití volné úvaby ochránce by bylo vbodné nalezená kritéria aplikovat. V závèru jsou predstaveny možnosti, jakým zpuisobem lze externě prezkoumat to, zda ochránce pravidla regulujicí jeho cinnost dodræ̌uje.
\end{abstract}

\section{Klíčová slova}

Veřejný ochránce práv; volné uvážení; pravidla činnosti; principy.

\begin{abstract}
The paper deals with the issue of whether the conduct of the Public Defender of Rights, an institution largely without a prescribed set of rules of conduct, is regulated by other rules and criteria other than the Acts. It focuses on the issue of how the rules can affect the Defender's discretion. The first part of the paper thus describes which types of the Defender's activities can be seen as discretionary. The main part of the paper then focuses on analysis which rules can be applied to the Defender's conduct and their discretion. Then the paper deals with the issue which types of Defender's activities should be governed by the presented rules. The final part focuses on the possibilities of the review of the Defender's compliance with the rules.
\end{abstract}

\section{Keywords}

Public Defender of Rights; Discretion; Rules of Conduct; Principles.

\footnotetext{
* Mgr. Anna Chamráthová, Katedra správní vědy a správního práva, Právnická fakulta, Masarykova univerzita, Brno / Department of Administrative Studies and Administrative Law, Faculty of Law, Masaryk University, Brno, Czech Republic / E-mail: anna.chamrathova@mail.muni.cz
} 


\section{Úvod $^{1}$}

Veřejný ochránce práv ${ }^{2}$ je specifickým státním orgánem, jednímž z charakteristických a základních znaků jeho činnosti je neformálnost a osvobození od procesních pravidel spolu s velkou mírou volnosti při výkonu této činnosti. Ze samotné povahy tohoto orgánu vyplývá, že má širokou volnost při výběru prostředků, kterými bude provádět svou činnost, popř. zda v některých prrípadech vůbec tyto prostředky uplatní. V tomto ohledu lze vysledovat určitou podobnost s orgány veřejné správy, resp. s uplatňováním jejich diskrece či správního uvážení. Stejně jako v jejich případě je totiž ochránci mnohdy dáno ke zvážení, jakým způsobem bude jednat či zda vůbec bude jednat.

$\mathrm{Na}$ činnost těchto orgánů obecně a na uplatňování jejich diskrečních oprávnění se však vztahují poměrně podrobná pravidla stanovená jak zákonem, tak nejrůznějšími právními zásadami. Právě zmiňovaným osvobozením od procesních pravidel a rozsáhlou možností ochránce využít své vlastní úvahy se ale tato instituce od klasických státních orgánů liší. V podstatě jediný komplexní soubor pravidel, která předepisují, jak by měla činnost ochránce vypadat, se nachází v zákoně o veřejném ochránci práv. ${ }^{4}$ Tento zákon nicméně z logiky věci upravuje postupy ochránce poměrně stručně. Co se limitů využití volné úvahy ochránce týče, nad rámec obecných požadavků na výkon funkce ochránce nestanoví př̀edmětný zákon téměř žádné.

Otázkou je, zda lze na činnost ochránce a využívání jeho volné úvahy vztáhnout i jiná pravidla či kritéria, například ta, které se uplatní při užití správního uvážení. Je totiž zřetelné, že v mnoha případech se činnost ochránce činnosti veřejné správy z velké části blíží; její podstatou je totiž kontrola veřejné správy a snaha o její zlepšení a zefektivnění a po dalších rozšíření působnosti ochránce i kontrola působení některých soukromých

1 Za poskytnutí Etického kodexu Kanceláře veřejného ochránce práv a názoru z Kanceláře na pojednávanou problematiku tímto děkuji Mgr. Davidu Slováčkovi, vedoucímu sekretariátu ochránce a jeho zástupce.

2 Dále také jen „ochránce“. Pro současnou představitelku instituce se sice užívá označení „veřejná ochránkyně práv“ či jen „ochránkyně“, v článku se však přidržuji pojmu „ochránce“ ve smyslu označení této instituce.

3 Odborná literatura běžně používá tyto pojmy jako synonyma. Srov. MATES, Pavel. Správní uvážení. Plzeň: Aleš Čeněk, 2013, s. 80 a násl. ISBN 978-80-7380-424-4; SKULOVÁ, Soňa. Správní uvážení: qákladní charakteristika a souvislosti pojmu. Brno: Masarykova univerzita, 2003, s. 8. ISBN 80-210-3237-5; a PRU゚CHA, Petr. Správni právo: obecná část. 8., dopl. a aktualiz. vyd. (V nakl. Doplněk 3.). Brno: Doplněk, 2012, s. 113. ISBN 978-80-7239-281-0.

4 Zákon č. 349/1999 Sb., o Veřejném ochránci práv, ve znění pozdějších předpisů (dále jen ,zákon o veřejném ochránci práv"; v př́padě citace předpisu novelizujícího tento zákon je citován jako zákon č. 349/1999 Sb., o Veřejném ochránci práv, jelikož uvádím plné oficiální názvy novel).

5 Srov. $\int 1$ odst. 1 zákona o veřejném ochránci práv, dle nějž ochránce „puisobí k ochraně osob před jednáním úradů a dalšich instituci wvedených v tomto zákoné, pokud je v rozporu s právem, neodpovídá principuim demokratického právníbo státu a dobré správy, jakož i pred jejich nečinností, a tím prispivá ke ochraně základních práv a svobod. " 
subjektů ve vybraných oblastech. ${ }^{6} \mathrm{~V}$ demokratickém právním státě dále neexistuje absolutní volnost úvahy při činnosti jakéhokoli orgánu. ${ }^{7}$ Domnívám se tedy, že jistá pravidla a kritéria vztahující se na činnost ochránce a využívání jeho volné úvahy nad rámec zákona o veřejném ochránci práv by měla být vysledovatelná, popř. dovoditelná. Ačkoliv je evidentní, že užití volného uvážení ochráncem většinou vyplývá ze samotného charakteru této instituce a jeho omezením by se vytratil právě tento její podstatný rys, nepovažuji to v některých př́padech za zcela vyloučené. Lze také říci, že určitá pravidla pro činnost ochránce, resp. pro uplatnění jeho uvážení, by měla existovat, a to pro upevnění jeho pozice jako morální autority.

Cílem tohoto článku je analýza, zda pro činnost ochránce existují nějaká kritéria, jimiž se musí řídit, a o jaká kritéria se př́padně jedná. Jelikož pro tento účel je podstatné, zda se jedná o druh činnosti, při němž má ochránce možnost volného uvážení či nikoli, popisuje první část článku, ve kterých prrípadech se volná úvaha ochránce uplatňuje. Následně se článek zabývá možnými pravidly, která lze obecně na činnost ochránce vztáhnout a jaká kritéria pro užití jeho volné úvahy lze nalézt. Závěrečné část se zamýšlí, zda lze na konkrétní případy užití volné úvahy ochráncem nalezená kritéria aplikovat, aniž by se tím vytratil jeden ze základních charakteristických rysů této instituce, a zda je možné provádět vnější kontrolu toho, jak ochránce pravidla vztahující se na jeho činnost dodržuje. Článek také ve vybraných případech provádí srovnání s Evropským veřejným ochráncem práv, britskými Komisaři pro místní samosprávu a Parlamentním komisařem pro administrativu, což jsou stejně jako ochránce ombudsmanské instituce fungující obdobným zpo̊sobem jako on. ${ }^{8}$

6 Lze zmínit např̀ úkol ochránce navštěvovat zařízení, v nichž se nachází či mohou nacházet osoby omezené na svobodě (svěřeno mu novelou zákona o veřejném ochránci práv - zákonem č. 381/2005 Sb., kterým se mění zákon č. 349/1999 Sb., o Veřejném ochránci práv, ve znění pozdějších předpisů, a některé další zákony, ve znění pozdějších předpisů; dále také jen ,zařžneni"), jeho antidiskriminační agendu (svěřeno mu novelou zákona o veřejném ochránci práv - zákonem č. 198/2009 Sb., o rovném zacházení a o právních prostředcích ochrany před diskriminací a o změně některých zákonů (antidiskriminační zákon), ve znění pozdějších předpisů) či jeho úkol sledovat naplňování mezinárodní smlouvy upravující práva osob se zdravotním postižením (svěřeno mu novelou zákona o veřejném ochránci práv - zákonem č. 198/2017 Sb., kterým se mění zákon č. 349/1999 Sb., o Veřejném ochránci práv, ve znění pozdějších předpisů).

7 Absolutní volnost by totiž znamenala libovưli, jejíž zákaz např. V. Šimíček považuje za náležitost právního státu. ŠIMÍČEK, Vojtěch. Čl. 1 odst. 1 Ústavy. In: BAHÝLOOVÁ, Lenka a kol. Ústava České republiky: komentár. Praha: Linde, 2010, s. 28. ISBN 978-80-7201-814-7.

8 Srov. čl. 228 Smlouvy o fungování Evropské unie a rozhodnutí Evropského parlamentu 94/262/ ESUO, ES, Euratom ze dne 9. 3. 1994 o pravidlech a obecných podmínkách pro výkon funkce veřejného ochránce práv; KOFLER, Brigitte. United Kingdom of Great Britain and Northern Ireland. In: KUCSKO-STADLMAYER, Gabriele (ed.). European ombudsman-institutions: a comparative legal analysis regarding the multifaceted realisation of an idea. Wien: Springer, 2008, s. 433-441. ISBN 978-3-211-72880-2. 


\section{Možnosti užití volné úvahy ochránce}

Pro stanovení pravidel, jimž by se ochránce měl při své činnosti ř́dit, a kritérií, na jejichž základě by měl uplatňovat svou volnou úvahu, je nutné odlišovat, zda se jedná o druh činnosti, při níž ochránce má volné uvážení $\mathrm{k}$ dispozici. Ač se jedná o instituci zásadně nepodléhající pevným procesním pravidlům, pro některé činnosti a situace mu zákon o veřejném ochránci práv předepisuje postup, od nějž se nemůže odchýlit. Jedná se např. o jeho nakládání s podněty spadajícími do jeho působnosti a splňujícími požadované náležitosti či určité fáze jeho šetření. $V$ naprosté většině př́padů však ochránci konkrétní postup, jak se má zhostit výkonu svých působností, provádět šetření a činit doporučení šetřeným subjektům, stanoven není. Jak již totiž bylo uvedeno, rozsáhlé možnosti využití volné úvahy při činnosti ochránce vyplývají ze samé podstaty této instituce. To se projevuje nejen $\mathrm{v}$ tom, že ochránce dle svého uvážení volí způsoby svého postupu a navrhuje prostředky $\mathrm{k}$ nápravě závadné situace, ale $\mathrm{v}$ mnoha jiných aspektech jeho činnosti. Nejvyšší soud na podzim roku 2016 uvedl: „Veřejný ochránce práv v̌̌ak rozhoduje o tom, zda je tréba v zájmu těchto osob [osob, jejichž zájmy chrání - pozn. aut.] využít kompetence, které mu svèruje zákeon, či z da k tomu divod není. V závèru z šetréeni veréjnébo ochránce práv se pak vỉle subjektü, které jsou predmètem toboto šetrení, nemůře promitnout. "

$\mathrm{V}$ některých př́padech je využití volné úvahy ochráncem $\mathrm{v}$ právní úpravě výslovně uvedeno, $v$ některých naznačeno a $\mathrm{v}$ některých je lze vyvodit $\mathrm{z}$ povahy věci. Tato kapitola se zabývá těmi nejtypiččěšími a nejpodstatnějšími z nich. Především, ochránce sám rozhoduje, zda považuje za vhodné či nutné užít některá specifická oprávnění svěřená mu př̀evážně zvláštními zákony. Konkrétně se může jednat nap̌r. o návrh na prrijetí, změnu či zrušení právního či vnitřního předpisu, ${ }^{10}$ podání návrhu $\mathrm{k}$ Ústavnímu soudu na zrušení právního předpisu jiného než zákona či účast $\mathrm{v}$ řízení o zrušení jakéhokoli právního předpisu, ${ }^{11}$ podání žaloby ve veřejném zájmu proti správnímu rozhodnuti ${ }^{12}$ a podání návrhu na zahájení kárného rízení proti př̌edsedům a místopředsedům soudů. ${ }^{13}$ Některé další př́pady volné úvahy ochránce stanoví př́mo zákon o veřejném ochránci práv. Při působnosti v oblasti kontroly veřejné správy ochránce jedná na základě podnětu fyzické nebo právnické osoby (slovy zákona „stě̌̌ovatele") nebo z vlastní iniciativy. Pokud má podnět zákonem stanovené náležitosti, ochránce se jím musí zabývat a situaci šetrìit. Když ovšem podnět některé náležitosti nemá, zákon o veřejném ochránci práv stanoví, že ochránce může podnět odložit. Ochránci je tedy v tomto př́padě výslovně dána

9 Rozsudek Nejvyššího soudu ze dne 27. 9. 2016, sp. zn. 30 Cdo 4118/2015.

10 \22 zákona o veřejném ochránci práv.

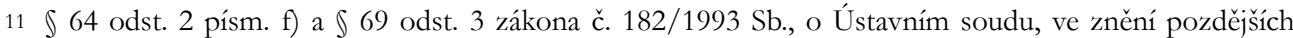
předpisů.

12 \66 odst. 3 zákona č. 150/2002 Sb., soudní řád správní, ve znění pozdějších předpisů.

13 Zákon č. 7/2002 Sb., o řízení ve věcech soudců, státních zástupců a soudních exekutorů, ve znění pozdějších předpisů. 
možnost zvážit, zda se věcí bude zabývat nebo ne. Odložení podnětu pouze musí být stěžovateli písemně zdůvodněno. Výslovné zakotvení volného uvážení, zda se ochránce bude podnětem zabývat, je pro tuto instituci, resp. její obdobu ve světě typické. ${ }^{14}$ I zahajování šetření z vlastní iniciativy je plně v diskreci ochránce. ${ }^{15}$

Co se samotného průběhu šetření prováděného ochráncem týče, ochránce bez zásadního omezení vybírá, jaké prostředky šetření ${ }^{16}$ zvolí a jakým způsobem bude probíhat komunikace se šetřeným. Zákon o veřejném ochránci práv dále uvádí demonstrativní výčet opatření k nápravě závadné situace, která může ochránce šetřenému navrhnout uplatnit, ochránci však nic nebrání doporučit i opatření v zákoně o veřejném ochránci práv neuvedené.

Ochránci je tedy dáno ke zvážení, jaký prostředek nápravy navrhne, je však limitován $\mathrm{v}$ úvaze, zda vůbec opatření $\mathrm{k}$ nápravě navrhne. Pokud totiž shledá v činnosti šetřeného pochybení a šetřený se na jeho výzvu k tomuto bud’ nevyjádří nebo neprovede z pohledu ochránce dostatečná opatření k nápravě, ochránce vydá závěrečné stanovisko, které návrh opatření k nápravě obsahuje obligatorně. Ač to zákon o veřejném ochránci práv výslovně neuvádí, z charakteru instituce ochránce vyplývá i jeho oprávnění doporučovat přijetí opatření $\mathrm{k}$ nápravě $\mathrm{v}$ průběhu celého šetření, nejen v rámci závěrečného stanoviska. $V$ těchto př́padech by záleželo plně na jeho úvaze nejen to, jaký druh opatření doporučí, ale i to, zda vůbec takové doporučení učiní.

Ochránce také může v rámci řešení obecnějších problémů činit různá doporučení, vydávat stanoviska a metodické pomůcky, pořádat konference a semináře či jednat s představiteli orgánů státních či územních samosprávných celků. V těchto př́padech opět záleží na něm, zda některý z těchto prostředků užije a jaký problém k řešení si zvolí.

Jak již bylo uvedeno, ochránce kromě kontroly veřejné správy vykonává i působnosti jiné. ${ }^{17} \mathrm{~V}$ případě provádění návštěv zařízení a tzv. sledování vyhoštění ${ }^{18}$ může, co se užití

14 Srov. např. FRAHM, Michael. Australasia and Pacific Ombudsman Institutions [online]. Berlin, Heidelberg: Springer, 2012, s. 59-60 [cit. 8. 12. 2018]. ISBN 978-3-642-33896-0. Dostupné z: https://link.springer. com/chapter/10.1007/978-3-642-33896-0_4\#citeas; nebo GREGORY, Roy a Peter HUTCHESSON. The Parliamentary Ombudsman: a Study in the Control of Aministrative Action. London: Allen\&Unwin for the Royal Institute of Public Administration, 1975, s. 215-246. ISBN 0-043-28009-9.

15 I tento způsob užití volné úvahy ochránce je ve světě běžný, srov. např. KUCSKO-STADLMAYER, Gabriele. The Legal Structures of Ombudsman-Institutions in Europe - Legal Comparative Analysis. In: KUCSKO-STADLMAYER, Gabriele (ed.). European ombudsman-institutions: a comparative legal analysis regarding the multifaceted realisation of an idea. Wien: Springer, 2008, s. 21. ISBN 978-3-211-72880-2.

16 Zákon sice obsahuje výčet toho, co smí ochránce požadovat a provádět, tento seznam je však natolik široký, že ochránce může být jen těžko při své činnosti v tomto směru zásadně omezen.

17 Provádět analýzu těchto působností a odlišností jejich výkonu od základní působnosti ochránce přesahuje cíle tohoto článku, který se tak soustředí především na základní působnost ochránce a z ostatních působností především na aspekty tzv. zveřejňování.

18 Konkrétně se jedná o sledování zajištění cizinců a výkonu správního vyhoštění, předání nebo průvozu zajištěných cizinců a trestu vyhoštění cizinců, kteří byli vzati do vyhošt'ovací vazby nebo kteří vykonávají trest odnětí svobody ( $\int 1$ odst. 6 zákona o veřejném ochránci práv). 
jeho volné úvahy týče, především výslovně doporučovat opatření k nápravě. Záleží přitom na jeho úvaze, zda tato doporučení učiní. Může si také volit, která zařízení v rámci své kontrolní činnosti vưči nim navštíví, zákon mu v tomto směru pouze ukládá povinnost, že tato jeho činnost musí být systematická. Konkrétní způsoby výkonu uvedených oprávnění jsou ponechány na volbě ochránce. $V$ prrípadě antidiskriminační agendy ochránce a jeho činnosti při sledování naplňování mezinárodní smlouvy upravující práva osob se zdravotním postižením či naplňování práva volného pohybu občanů Evropské unie mu jsou stanoveny rámcové úkoly (opět nap̌r. vydávání doporučenî), které by měl vykonávat, a konkrétní prostředky k jejich plnění jsou ponechány na jeho volbě.

Zákon o veřejném ochránci práv obsahuje ještě jeden významný případ užití volné úvahy ochránce, a to je tzv. zveřejňování. $V$ dále zmíněných situacích se ochránce mưže rozhodnout, že bude případ medializovat, včetně uvedení jména a příjmení osob, které jsou oprávněné jednat jménem šetřeného. $K$ tomuto kroku může přistoupit tehdy, když šetřený ani po doručení závěrečného stanoviska (viz výše) ochránci nesdělí, jaká opatření k nápravě provedl, nebo jsou provedená opatření dle názoru ochránce nedostatečná a dále tehdy, když šetřený nesplní povinnost součinnosti vůči ochránci nebo když úřad, kterému doporučil přijetí, změnu či zrušení právního či vnitřního předpisu, $\mathrm{k}$ tomuto nesdělí své stanovisko. $V$ případě nesplnění povinnosti součinnosti lze popsaným způsobem věc medializovat i tehdy, když se jedná o provádění návštěv zařízení, v nichž se nachází nebo mohou nacházet osoby omezené na svobodě, sledování vyhoštění, činnosti při sledování naplňování mezinárodní smlouvy upravující práva osob se zdravotním postižením a naplňování práva volného pohybu občanů Evropské unie.

Vhodným zpo̊sobem ochránce dále zveřejňuje i zprávy z návštěv zařízení, zprávy ze sledování vyhoštění včetně obdržených vyjádření a vybrané zprávy o ukončených šetřeních $\mathrm{v}$ jednotlivých věcech a soustavně seznamuje veřejnost s poznatky vyplývajícími z jeho činnosti ( $\int 23$ odst. 2 zákona o veřejném ochránci práv). Za účelem informování o své činnosti mu je povinnost zveřejňovat zprávy a doporučení uložena i v rámci jeho působnosti v oblasti diskriminace [ $\int 21 \mathrm{~b}$ písm. c)], sledování naplňování mezinárodní smlouvy upravující práva osob se zdravotním postižením [\$ 21c odst. 1 písm. c)] a naplňování práva volného pohybu občanů Evropské unie [ $\int 21 \mathrm{~d}$ odst. 1 písm. c)]. V těchto př́padech mu však není umožněno uvádět jména a př́ijmení osob oprávněných jednat jménem šetřeného.

Záleží tedy na ochránci, jakým zpơsobem zveřejnění zpráv nebo svých poznatků provede a zda $\mathrm{v}$ některých př́padech vưbec provede samotné zveřejnění. Zde považuji za potřebné poznamenat, že u prvního uvedeného okruhu situací, kdy může ochránce věc zveřejnit, je toto zveřejnění jednoznačně konstruováno jako sankce ${ }^{19}$ př́ślušnému subjektu za nesplnění povinnosti vưči ochránci, přičemž v některých prrípadech se může

19 Tomu nasvědčuje i znění důvodové zprávy k zákonu č. 381/2005 Sb., změna zákona o Veřejném ochránci práv. 
jednat i o soukromé subjekty. Do určité míry také tento případ zveřejnění ochráncem plní obdobné funkce jako zveřejnění rozhodnutí o přestupku. ${ }^{20}$ Co se zveřejňování dále týče, široká možnost uvážení u zveřejňování s výhradně informačním účelem (tj. nikoli jako sankce) je obecně pro ombudsmanské instituce typická. ${ }^{21}$

Závěrem je nutné upozornit na specifickou výjimku, kdy dochází k informování o činnosti ochránce nikoli $\mathrm{v}$ popsaném režimu zveřejňování dle zákona o veřejném ochránci práv, ale dle zákona č. 106/1999 Sb., o svobodném př́istupu k informacím, ve znění pozdějších př̀edpisů. V těchto případech je Kancelář veřejného ochránce práv subjektem povinným $\mathrm{k}$ poskytování informací2 ${ }^{22}$ podle tohoto zákona a vystupuje tak jako klasický správní orgán, na jehož činnost se vztahuje správní řád. ${ }^{23}$ Stejně jako v případě jiných správních orgánů je možné se proti rozhodnutím o odmítnutí poskytnout informace bránit i ve správním soudnictví. ${ }^{24}$ Tato situace se tedy z problematiky tohoto článku zcela vymyká, jelikož na ochránce, resp. Kancelář, se v tomto př́ípadě vztahují stejná pravidla činnosti jako na „klasické“ správní orgány. Případná možnost jeho volné úvahy je zde správním uvážením v pravém slova smyslu a vztahují se na ni bez dalšího stejná pravidla a limity jako na užití správního uvážení jiných správních orgánů.

\section{Pravidla a kritéria obecně vztažitelná na činnost ochránce}

Tato kapitola se zabývá otázkou, která pravidla a kritéria se byt' potenciálně mohou na činnost ochránce vztahovat, za účelem následné analýzy, jakým způsobem je možné je na jeho činnost a především na využití jeho volné úvahy uplatnit. Jak již totiž bylo uvedeno, v demokratickém právním státě by absolutní volnost uvážení neměla existovat ${ }^{25}$ a lze se domnívat, že určité limity a procesní pravidla by na činnost ochránce uplatňovány být měly.

Přístup opačný pak může vést $\mathrm{k}$ poměrně absurdním závěrům, kdy se např. Nejvyšší správní soud vyjádřil, že ochránci z vůbec žádného právního předpisu neplyne povinnost vést spisy: „I kedyž zpovaby činnosti [ochránce - pozn. aut.] vyplývá, že podané podnèty jsou nějakým zpuisobem evidovány a v prüpadé potřeby o nich jsou vedeny i spisy, neni to povinnost vyplývajicí z. néjakého právníbo predpisu. Ani zákon č. 349/1999 Sb. ani žádný jiný zákon neupravuje bliže

20 Srov. důvodovou zprávu k zákonu č. 250/2016 Sb., o odpovědnosti za přestupky a řízení o nich a důvodovou zprávu k zákonu č. 381/2005 Sb., změna zákona o Veřejném ochránci práv.

21 KUCSKO-STADLMAYER, op. cit., s. 49.

22 Vedoucí Kanceláře poté rozhoduje o odvoláních proti rozhodnutím Kanceláře a stížnostech na postup při vyřizování žádosti o informace.

$23 \int 1$ odst. 1 zákona č. 500/2004 Sb., ve znění pozdějších předpisů (dále jen „spráuní rád“).

24 Průlomovým judikátem v této věci, který se zároveň zabýval obecnou otázkou, zda je možné ochránce považovat za správní orgán v režimu správního řádu, je rozsudek Nejvyššího správního soudu ČR ze dne 19. 2. 2008, č. j. 2 As 58/2007-52; blíže o něm bude pojednáno dále.

25 Viz ŠIMÍČEK, Vojtěch. Čl. 1 odst. 1 Ústavy. In: BAHÝL’OVÁ, Lenka a kol. Ústava České republiky: komentár. Praha: Linde, 2010, s. 28. ISBN 978-80-7201-814-7. 
zpuisob a procesni otázky činnosti žalovaného a neukládá mu ani povinnost vést spisy. "26 I když lze tento vývod považovat za ne zcela logický ze samotné povahy věci, opak lze dovodit i ze zákona o veřejném ochránci práv. Jeho $\int 7$ odst. 4 totiž upravuje okolnosti, kdy mají státní orgány možnost nahlížet do spisů ochránce. Kdyby tedy ochránce žádné spisy nevedl, nebylo by nutné upravovat nahlížení do nich.

Co se okruhů př́padných pravidel a kritérií týče, lze uvažovat především o těch stanovených v samotném zákoně o veřejném ochránci práv, těch, které si stanovil sám ochránce, nejrůznějších právních principech a zásadách a kritériích mimoprávních.

\subsection{Pravidla stanovená zákonem o veřejném ochránci práv}

Cílem tohoto článku sice je analyzovat pravidla vztahující se na činnost ochránce nad rámec zákona o veřejném ochránci práv, jelikož u těchto je nesporné, že se na ni vztahují, přesto považuji za vhodné je alespoň stručně představit a zdůraznit, která se vztahujî přímo na využití jeho volné úvahy. Jak již bylo uvedeno, tento zákon jako jediný komplexně upravuje činnost ochránce, nepovažuji tedy za nutné se zabývat jinými zákony, které upravují některé specifické aspekty využívání jeho zvláštních oprávnění. ${ }^{27}$

Poměrně paradoxní ovšem je, že úprava postupů ochránce obsažená v zákoně o veřejném ochránci práv, tj. jediného komplexního souboru pravidel v tomto směru, o němž nelze pochybovat, že se na činnost ochránce vztahuje, je poměrně kusá a mnohdy nejednoznačná nejen co do obecných kritérií, ale i co do konkrétnějších pravidel. V tomto ohledu by zřejmě byla vhodná určitá korekce.

Např́lklad \11 zákona o veřejném ochránci práv stanovuje určité náležitosti, které musí mít podnět ochránci adresovaný, a následně $\int 12$ odst. 2 písm. a) tohoto zákona uvádí, že pokud chybějící náležitosti nebyly doplněny ve stanovené lhůtě, může ochránce podnět odložit. Neexistuje nicméně úprava postupu ochránce v „mezidobi““ od doručení podnětu s chybějícími náležitostmi do jeho odložení z důvodu jejich nedoplnění. Je sice bez větších problémů dovoditelné, že ochránce má vyzvat stěžovatele, aby náležitosti doplnil, a stanovil mu k tomu lhůtu, přesto se však lze tázat, proč tato povinnost není výslovně upravena. Zde lze poukázat na úpravu ve slovenském zákone o verejnom ochrancovi prav $^{28}$, který se v mnoha ohledech do velké míry podobá českému zákonu o veřejném ochránci práv. Slovenský zákon obsahuje explicitně předepsaný postup ochránce v př́padě, kdy vyzývá stěžovatele $\mathrm{k}$ doplnění chybějících náležitostí podnětu (\$13 odst. 3).

Za poněkud zvláštní lze považovat i konstrukci zveřejnění př́ípadu jako sankce za nesplnění povinnosti součinnosti vưči ochránci u sledování vyhoštění a návštěv zařízení. \21a odst. 1 zákona o veřejném ochránci práv totiž požaduje pouze přiměřené užití

26 Rozsudek Nejvyššího správního soudu ČR ze dne 19. 2. 2008, č. j. 2 As 58/2007-52.

27 Viz pozn. č. 10-13.

28 Zákon č. 564/2001 Z.z., o verejnom ochrancovi prav, v znení neskorších predpisov. 
ustanovení \15 a 16 zakotvujících povinnost součinnosti vůči ochránci, odst. 5 však umožňuje ochránci zveřejnění při nesplnění povinnosti součinnosti upravené v $\int 15$ a 16 beze zbytku, a přiměřenost užití ustanovení o povinnosti součinnosti se tak v prrípadě tohoto druhu zveřejňování vytrácí. Zákonodárce původně zamýšlel, aby došlo ke vztažení užití \15 až 16 obdobněa odst. 5 poté navázal stanovením sankce za nesplnění povinností z \15 až 16 plynoucích, v legislativním procesu však došlo ke změně z ,obdobně“ na ,priméreně", aniž by byla provedena změna v navazujícím odst. 5. Za problematické lze považovat, že tato úprava byla bez dalšího automaticky přejímána i při úpravě působností ochránce v oblasti sledování naplňování mezinárodní smlouvy upravující práva osob se zdravotním postižením či naplňování práva volného pohybu občanů Evropské unie (viz \21c a $\int 21 \mathrm{~d}$ ).

Co se obecnějších pravidel a kritérií týče, zákon o veřejném ochránci práv vymezuje působnost ochránce a uvádí, že ochránce vykonává svou funkci nezávisle a nestranně, je ale za její výkon odpovědný Poslanecké sněmovně. Ochránce také skládá slib, ve kterém kromě nezávislosti a nestrannosti výkonu své funkce slibuje, že bude funkci vykonávat v souladu s Ústavou a ostatními zákony a že bude chránit neporušitelnost práv. Dále je uvedeno, že ochránce není oprávněn zasahovat do činnosti a rozhodování úřadů a zařízení jinak, než jak stanoví zákon o veřejném ochránci práv. \1 odst. 1 ještě požaduje, aby činnost ochránce přispívala k ochraně základních práv a svobod. Toto ustanovení obsahuje také kritéria, dle kterých má ochránce posuzovat jednání úradů a jiných institucí. Kromě zákonnosti se jedná o soulad s principy demokratického právního státu a dobré správy a zákaz nečinnosti. Domnívám se, jak bude rozvedeno dále, že ochránce vystupující z pozice morální autority a sloužící jako pozitivní př́klad, je těmito kritérii vázán rovněž, jelikož by veřejnou správu a jiné kontrolované subjekty jen těžko mohl motivovat ke zkvalitnění jejich jednání, kdyby je sám nedodržoval.

Samotný postup ochránce při šetření prováděných v rámci jeho základní působnosti vưči veřejné správě (včetně provádění systematických návštěv a sledování vyhoštění, které představují pouhou modifikaci tohoto postupu) je poněkud paradoxně poměrně rigidní, pevně předepisující sled kroků, které ochránce má dodržet a nepř́liš reflektující možnost neformálního kontaktu a řešení se šetřeným. A. Šabatová ve své knize Ombudsman a lidská práva označuje postup ochránce za až př́liš podrobně upravený, ze struktury jejího textu však nelze seznat, zda se tento názor vztahuje jen k provádění systematických návštěv a sledování vyhoštění, či i k postupu v ochráncově základní pưsobnosti. ${ }^{29} \mathrm{~V}$ prípadě antidiskriminační agendy, sledování naplňování upravující práva osob se zdravotním postižením a naplňování práva volného pohybu občanů Evropské unie ochránci není stanoven žádný postup, pouze, jak již bylo zmíněno, jen rámcové úkoly, které má plnit.

29 ŠABATOVÁ, Anna. Ombudsman a lidská práva. Brno: Doplněk, 2008, s. 128. ISBN 978-80-7239-229-2. 


\subsection{Pravidla stanovená samotným ochráncem}

Ochránci nic nebrání, aby si sám stanovil pravidla a kritéria, kterými se při své činnosti chce ř́idit, dokonce to lze považovat za velmi vhodné. Jelikož totiž úloha ochránce spočívá v tom, že se snaží co nejvíce zkvalitnit a zefektivnit působení veřejné správy ${ }^{30}$ silou své morální autority, je žádoucí, aby ukázal, že on sám na sebe klade obdobné standardy, jaké požaduje po těch, jejichž činnost kontroluje. Lze také dodat, že i stručnost právní úpravy v tomto směru $\mathrm{k}$ tomuto kroku vybízí. Inspirací v tomto ohledu je například postup Evropského veřejného ochránce práv, který přijal a zveřejnil nejen poměrně podrobné prováděcí rozhodnutî ${ }^{31} \mathrm{k}$ rozhodnutí Evropského parlamentu v základu regulujícího jeho činnost ${ }^{32}$, ale také etický kodex, kterým se při své činnosti hodlá ř́ditit a další úpravy některých postupů a otázek při jeho činnosti vznikajících ${ }^{34}$.

Ochránce sám v tomto směru zveřejnil pouze stručnou Strategii rozvoje Kanceláře veřejného ochránce práv na roky 2016-202135, ve které zdůrazňuje, že si přeje vykonávat práci kvalitně a efektivně, s důrazem na profesionalitu, otevřenost a důstojnost. ${ }^{36}$ Jiný soubor pravidel, podle kterých při výkonu své působnosti postupuje, zveřejněn nebyl, ${ }^{37}$ byt' takováto pravidla existují. Ochránce například přijal Etický kodex Kanceláře veřejného ochránce práv, který upravuje obecné etické zásady, kterými se mají rídit zaměstnanci Kanceláře, a etické zásady vztahující se na činnost právníků právního odboru Kanceláre. ${ }^{38}$ Nelze vyloučit ani existenci jiných obdobných interních pravidel, která však nejsou veřejně př́stupná.

30 Popř. dalších subjektů spadajících do jeho působnosti.

31 Rozhodnutí Evropské veřejné ochránkyně práv, kterým se přijímají prováděcí pravidla 2016/C 321/01 ze dne 20. 7. 2016.

32 Rozhodnutí Evropského parlamentu 94/262/ESUO, ES, Euratom ze dne 9. 3.1994 o pravidlech a obecných podmínkách pro výkon funkce veřejného ochránce práv.

33 O'REILLY, Emily. Code of Conduct for the European Ombudsman. European Ombudsman [online]. [cit. 31. 12. 2018]. Dostupné z: https://www.ombudsman.europa.eu/cs/emily-oreilly/ethics-and-conduct/ code-of-conduct/en

34 Viz Další dokumenty. Evropský veřejný ocbránce práv [online]. Evropská unie, (C) 1995-2019 [cit. 31. 1. 2019]. Dostupné z: https://www.ombudsman.europa.eu/cs/legal-basis/other-documents. Konkrétně lze jmenovat např. rozhodnutí evropského veřejného ochránce práv týkající se žádostí o přezkum a rozhodnutí, kterým se vydávají pokyny pro postup $\mathrm{v}$ př́padě nepatřičné komunikace a stížností, které představují zneužití procesu.

35 Strategie rozvoje Kanceláře veřejného ochránce práv 2016-2021. Kancelár veřejnébo ochránce práv [online]. 5 s. [cit. 31. 12. 2018]. Dostupné z: https://www.ochrance.cz/fileadmin/user_upload/Kancelar/strategie_KVOP_2016-2021.pdf

36 Ibid, s. 5.

37 Statut a Organizační rád zveřejněné na webových stránkách ochránce upravují pouze záležitosti organizačního charakteru. Viz Statut Kanceláre veřejného ochránce práv. Kancelár veréjného ochránce práv [online]. [cit. 21. 12. 2018]. Dostupné z: https://www.ochrance.cz/kancelar-vop/statut/; a Organizační ŕád. Kancelár verégného ochránce práv [online]. [cit. 31. 12. 2018]. Dostupné z: https://www.ochrance.cz/kancelar-vop/ statut/organizacni-rad/

38 Etický kodex Kanceláře veřejného ochránce práv. Kancelár veréjnébo ocbránce práv, s. 2. 
Vzhledem k uvedenému v prvním odstavci této podkapitoly však lze uvažovat o tom, zda by nebylo vhodné, aby ochránce pravidla, která si stanovil, zveřejnil. Prvoplánově totiž není dostupná ani informace o existenci citovaného etického kodexu, může se tedy jevit, že ochránce žádná interní pravidla v tomto směru nestanovil. Dokonce ani jednoznačně neuvádí, zda se cítí být vázán principy dobré správy, jejichž souboru je v českém prostředí autorem. ${ }^{39}$

\subsection{Zásady a principy ${ }^{40}$}

Lze dále uvažovat, zda na činnost ochránce a tedy i na užití jeho volné úvahy nevztáhnout některé skupiny obecných právních principů a zásad, zejména principy ústavní, principy dobré správy či jejich zákonný odraz - základní zásady činnosti správních orgánů nebo principy správního trestání.

\subsection{1 Ústavníprincipy}

Ústavní principy jsou kategorií přesně ohraničitelnou jen s obtížemi. Mnoho z nich je nadto obsaženo i v jiných katalozích principů nebo jsou v nich blížeji charakterizovány. To může působit problémy vzhledem $\mathrm{k}$ tomu, že se jedná o zřejmě jedinou kategorii právních principo̊, u nichž je jasné, že se vztahují na absolutně veškeré orgány ve státě existující a zavazující je při jejich činnosti. Nepochybně se tedy vztahují i na činnost ochránce a na užití jeho volné úvahy. S výjimkou zákonné úpravy se jedná o zřejmě jedinou skupinu kritérií, u nichž je nesporné, že je jimi ochránce přxi využívání své volné úvahy limitován. Vzhledem k výše uvedenému nicméně může být obtižnější určit, které principy se na činnost ochránce budou vztahovat z toho titulu, že jsou principy ústavními. Podle mého názoru však lze dovozovat, že každý princip, u kterého se doktrína či judikatura Ústavního soudu shodují na jeho ústavnosti, má potenciál se na činnost ochránce vztahovat.

Co se konkrétních takových principů týče, lze zmínit např́íklad princip proporcionality, legitimního očekávání adresátů jednání orgánu, jejich rovnosti a právní jistoty. Významným ústavním principem je i zákonnost, což se ale $\mathrm{v}$ př́padě užití volné úvahy ochránce prŕliš neuplatní, jelikož z logiky věci není v tomto směru mnoho zákonných pravidel, jak ostatně vyplývá z podkapitoly 2.1 Pravidla stanovená zákonem o veřejném ochránci práv. Dále lze uvést principy demokratického právního státu, které jsou ostatně jedním z kritérií, jímž by ochránce měl poměřovat činnost veřejné správy. Tím spíše by je tedy měl při své činnosti dodržovat i on sám.

39 ČERNÍN, K. Principy dobré správy definované veřejným ochráncem práv. In: HRABCOVÁ, Dana (ed.). Principy dobré správy. Brno: Masarykova univerzita, 2006, s. 11-17. ISBN 80-210-4001-7.

40 Ačkoli doktrína občas mezi pojmy zásada a princip rozlišuje, domnívám se, že pro účely tohoto článku to není nezbytné; používám tedy tyto pojmy promiscue. 


\subsubsection{Principy dobré správy}

Principy dobré správy lze vymezit jako kritéria, která by se veřejná správa v moderním demokratickém právním státě měla snažit co nejvíce naplňovat, aby se maximálně přiblížila svému poslání být především službou veřejnosti, ač k tomu v mnohých případech není z hlediska práva zavázána. Ochránce sice není orgánem veřejné správy, lze však spekulovat o tom, zda se na něj tyto principy také nevztahují. Jak např́iklad bylo v úvodu tohoto článku zmíněno, kontrolní činnost ochránce má z hlediska materiálního povahu správní činnosti. Lze také zdůraznit, že ochránce je v českém prostředí autorem těchto principů a zákon o veřejném ochránci práv mu ve svém $\int 1$ odst. 1 výslovně ukládá, aby dohlížel na jejich dodržování a prosazování. Bylo by tedy poněkud nelogické, kdyby se jimi on sám ve své praxi neřídil za účelem upevnění své pozice morální autority a poskytování pozitivního př́kladu pro veřejnou správu.

Jejich závaznost pro činnost ochránce však žrejmě bez dalšího prohlásit nelze, ač je zřejmě on sám ve své praxi dodržovat bude, byt' toto explicitně neuvádí (viz předchozí kapitola).

Zmínit lze, že na Evropského veřejného ochránce práv se principy dobré správy vztahují, v jeho případě je však tato skutečnost založena čl. 41 Listiny základních práv Evropské unie, dle nějž mají orgány Unie povinnost k tzv. řádné správě. ${ }^{41}$

\subsubsection{Základní zásady činnosti správnich orgánư ${ }^{42}$}

Vztažení základních zásad činnosti správních orgánů na užití volné úvahy ochránce se na první pohled může jevit jako nesmyslné, jelikož dle obecně prijímaného názoru ochránce není správním orgánem. V žádném případě zde nechci tvrdit, že by ochránce byl správním orgánem $\mathrm{v}$ doktrinálním slova smyslu, vzhledem $\mathrm{k}$ legální definici správního orgánu ve správním řádu ${ }^{43}$, však lze uvažovat o tom, že do jeho působnosti spadá právě v těch případech, kdy se jeho činnost silně blíží výkonu veřejné správy. Ochránce má totiž při výkonu své kontrolní činnosti určité vrchnostenské postavení - má oprávnění vstupovat do kontrolovaných prostor a provádět v nich šetření, přičemž kontrolované subjekty (může se přitom jednat o soukromé subjekty) mají povinnost mu k tomuto poskytnout součinnost. Při nesplnění této povinnosti o tomto může ochránce informovat veřejnost; sankční povaha tohoto zveřejnění již byla zmíněna.

41 Rádná správa $\mathrm{v}$ pojetí Listiny základních práv Evropské unie zahrnuje povinnost řešit záležitosti nestranně, spravedlivě a v přiměřené lhůtě, odůvodňovat rozhodnutí správních orgánů aj.

42 Tento oddíl a závěry v něm obsažené vychází a jsou z části přebrány z příspěvku publikovaného ve sborníku z konference Mílniky práva v stredoeurópskom priestore 2017. Viz CHAMRÁTHOVÁ, Anna. Vztahuje se na činnost veřejného ochránce práv správní rád? Milniky práva v stredoeurópskom priestore 2017 [online]. Bratislava: Univerzita Komenského v Bratislave, Právnická fakulta, 2017, s. 580-584 [cit. 31. 12. 2018]. ISBN 978-80-7160-445-7. Dostupné z: http://conference.flaw.uniba.sk/zborniky/files/M $\%$ C3\%AD $\% C 4 \% B E n i k y \% 20 p r \% C 3 \% A 1 v a \% 20$ (Milestones $\% 20$ of $\% 20 L a w) / 2017 / Z$ bornik_Milniky_2017.pdf

$43 \int 1$ odst. 1 správního řádu. 
Ustanovení \1 odst. 1 správního řádu správní orgány vymezuje jako všechny orgány moci výkonné, orgány územních samosprávných celků a jiné orgány a právnické a fyzické osoby, které vykonávají působnost v oblasti veřejné správy. Výkon působnosti v oblasti veřejné správy nicméně je, jak naznačuje komentářová literatura, vykládán různorodě a nejednoznačně. Jednotlivé komentáře jej vymezují různě a neshodují se např́iklad ani na tom, zda do působnosti správního řádu spadá normotvorba veřejné správy. ${ }^{44}$ Někteř́i odborníci jej ztotožňují s výkonem veřejné moci v oblasti veřejné správy či s výkonem veřejné správy ${ }^{45}$, je ovšem diskutabilní, zda pojem ,výkon veréjné správy “lze považovat za identický s pojmem ,výkon piisobnosti v oblasti verejné správy“. Dle některých odborníků se dále jedná pouze o vrchnostenskou veřejnou správu v kontrastu k veřejné správě vykonávané soukromoprávními prostředky ${ }^{46}$, dle jiných předmětný pojem zahrnuje i pečovatelskou veřejnou správu ${ }^{47}$ nebo různé informační úkony typu doporučení a výzev ${ }^{48}$.

Vzhledem naznačenému postavení ochránce vưči kontrolovaným subjektům je tedy otázkou, zda by pro účely správního řádu ochránce nemohl být považován za správní orgán. Většina zmíněné literatury vztahující působnost správního řádu jen na jednání správních orgánů skrze vrchnostenské nástroje totiž uvažuje pouze o protikladu těchto nástrojů k nástrojům soukromoprávním jako je uzavírání kupních smluv či prodej majetku, přičemž je očividné, že nástroje ochránce při výkonu jeho působnosti můžeme řadit mezi soukromoprávní jen těžko. Lze také podotknout, že čistě gramaticky vzato, působnost ochránce vykonává a v oblasti veřejné správy se tento výkon odehrává. Komentářová literatura dále sice obsahuje výslovné tvrzení, že na činnost ochránce se správní řád nevztahuje ${ }^{49}$, obsahuje však i zmínku o ochránci jako prríkladu jiného orgánu ve smyslu $₫ 1$ odst. 1 správního řádu ${ }^{50}$.

44 Srov. PRŮCHA, Petr. Sprámí rád: s poznámkami a judikaturou. 2. aktualiz. a dopl. vyd. Praha: Leges, 2015, s. 21. ISBN 978-80-7502-051-2; a SKULOVÁ, Soňa. Působnost správního řádu, zásady činnosti a nečinnost [Část I. Správní řád. Hlava II.]. In: Správní rád. 1. vyd. Praha: ASPI, 2006, s. 25 a 35. ISBN 80-7357-226-5.

45 Viz HRABÁK, Jan a Tomáš NAHODIL. Správní rád: s výkladovými poznámkami a vybranou judikaturou. 4. vyd. Praha: Wolters Kluwer ČR, 2012, s. 21. ISBN 978-80-7357-959-3; JEMELKA, Luboš a kol. Správní rád. 5. vyd. Praha: C. H. Beck, 2016, s. 2-4. ISBN 978-80-7400-607-4; ČERNÝ, Pavel. Působnost a systematika správního řádu. In: ČERNÝ, Pavel a kol. Prưvodce novým správním rádem: spodrobným výkladem a vzory podání. Praha: Linde, 2006, s. 27. ISBN 80-7201-600-8; ONDRUŠ, Radek. Správní rád: nový zákon s diovodovou zprávou a poznámkami. Praha: Linde, 2005, s. 30. ISBN 80-7201-523-0; a VEDRAL, Josef. Správní rád: komentár. 2. aktualiz. a rozš. vyd. Praha: Ivana Hexnerová - Bova Polygon, 2012, s. 15-16. ISBN 978-80-7273-166-4.

46 Viz JEMELKA, op. cit., s. 14; ČERNÝ, op. cit., s. 27; VEDRAL, op. cit., s. 16 a důvodová zpráva k zákonu č. 500/2004 Sb., správní řád.

47 POTĚŠIL, Lukáš. $\int 1$ [Předmět úpravy a rozsah působnosti]. In: POTĚŠIL, Lukáš a kol. Správní rád. 1. vyd. Praha: Nakladatelství C. H. Beck, 2016, s. 10. ISBN 978-80-7400-598-5.

48 HRABÁK, op. cit, s. 21.

49 ONDRUŠ, op. cit., s. 29.

50 ČERNÝ, op. cit, s. 25. 
Co se týče faktického dopadu pravidel obsažených ve správním řádu na činnost ochránce, jednalo by se pouze právě o základní zásady činnosti správních orgánů. Jakékoli jiné instituty obsažené ve správním řádu jsou, domnívám se, svou povahou natolik odlišné od výstupů ochránce, že uvažovat o vztažení jejich právní úpravy i na ochráncovy výstupy je nemožné i v rovině čistě teoretické. Základní zásady činnosti správních orgánů jsou nadto zákonnou obdobou principů dobré správy, jimiž by se ochránce jako jeden z jejich autorů a propagátorů koneckonců měl cítit vázán. Pro praktické uplatnění by ovšem bylo nutné posoudit, zda se ta která činnost ochránce do takové míry bliží činnosti veřejné správy, aby předmětné vztažení bylo možné. Jednalo by se zřejmě především o výkon jeho kontrolní činnosti a uplatnění $\mathrm{k}$ tomuto určených pravomocí, zvláště ve vztahu k soukromým subjektům.

Závěrem poznamenávám, že sám ochránce se názorem, že by se na něj měl v byt' jen takto omezené míre vztahovat správní řád, zásadně nesouhlasí. ${ }^{51}$ Je třeba prípustit, že toto jistě nebylo při tvorbě správního řádu cílem či úmyslem zákonodárce, způsob vymezení působnosti tohoto předpisu však dle mého názoru pro v tomto článku naznačenou interpretaci prostor dává. Jedná se nicméně především o problém znění příslušných ustanovení správního řádu a jejich výkladu, nikoli o závěr, že by se na činnost ochránce správní řád vztahovat měl.

\subsubsection{Principy správního trestání}

Jak již bylo zmíněno, v mnoha př́padech může mít tzv. zveřejňování prováděné ochráncem formu sankce. Nabízí se tak i otázka, zda by se na tyto situace neměly vztahovat i principy správního trestání, zvláště v př́padech, kdy dopadají na soukromé subjekty. $\mathrm{V}$ př́ípadě ochránce sice lze o správním trestání jen těžko hovořit, vzhledem k charakteru jeho činnosti se však jeho sankční mechanismus nejvíce blíží tomuto institutu. Jak již bylo zmíněno, do určité míry plní obdobné funkce jako zveřejnění rozhodnutí o přestupku. ${ }^{52}$ Ohledně sankčního zveřejnění ochráncem totiž zákonodárce uvádí: „Pro posí-

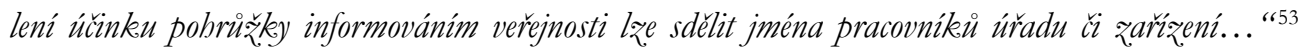
a u zveřejnění rozhodnutí přestupku zase: „V z̧hledem k tomu, že dobrá pověst je pro právnickou osobu značnou bodnotou, lze predpokládat, že brozba timto správnim trestem může mít určitý odstrašujicí účinek. " ${ }^{54}$ Domnívám se však, že činnost ochránce je i v tomto případě velmi specifická a ač zveřejnění plní některé z funkcí trestu, má funkci především informativní a funkce retributivní je potlačena. Požadavek uplatnění principů správního trestání na tuto oblast by tak př́liš zasáhl do charakteru instituce ochránce. Nevylučuji nicméně, že při prípadných dalších změnách jak v právní úpravě působnosti a činnosti ochránce,

\footnotetext{
51 Viz pozn. č. 1.

52 Viz pozn. č. 20.

53 Důvodová zpráva k zákonu č. 381/2005 Sb., změna zákona o Veřejném ochránci práv.

54 Důvodová zpráva k zákonu č. 250/2016 Sb., o odpovědnosti za přestupky a řízení o nich.
} 
tak v jeho vlastní praxi může být odpověd’ na rozebíranou otázku odlišná. Lze také podotknout, že ochránci nic nebrání se rozhodnout tyto principy při sankčním zveřejňování dobrovolně dodržovat.

\subsection{Kritéria etická a morální}

Jak již bylo několikrát uvedeno, autorita ochránce primárně nevyplývá z práva, ale z jeho postavení jako morální autority. Je proto dle mého názoru na místě uvažovat o tom, zda by se tedy na jeho činnost neměla vztahovat i kritéria zcela mimoprávní, především etická a morální. V činnostech jiných orgánů jsou tato kritéria obvykle pokryta jinými z předchozích jmenovaných skupin právních principů, např́klad principy dobré správy. Jelikož je ovšem diskutabilní, do jaké míry a zda vlastně se tyto skupiny principů vztahují i na činnost ochránce, měla by se kritéria etická a morální na jeho činnost vztahovat především.

\section{Možné uplatnění nalezených pravidel a kritérií na užití volné úvahy ochránce}

Zbývá ještě otázka, do jaké míry by ochránce měl kritéria popsaná v předchozí kapitole při své činnosti a zejména při užití své volné úvahy zohledňovat. Vzhledem k vysoké specifičnosti mnoha oblastí a způsobů jeho činnosti by nebylo rozumné požadovat, aby je uplatňoval ve všech př́padech a za všech okolností. Je totiž nutné zohlednit, kdy užití volné úvahy ochránce vyplývá z povahy této instituce a kdy se blíží uplatňování správního uvážení.

Nejvolnější režim by mělo mít uplatňování specifických oprávnění ochránce, jako je návrh na přijetí, změnu či zrušení právního či vnitřního předpisu, podání návrhu k Ústavnímu soudu apod., a také vydávání různých metodik a doporučení. V zásadě volnou ruku by ochránce měl mít i při výběru problematických témat, ke kterým se rozhodně veřejně vyjadřovat a snažit se o zlepšení stavu v těchto oblastech, za předpokladu, že spadají do jeho působnosti. $V$ těchto věcech by měl mít dle mého názoru téměř absolutní volnost užití své volné úvahy a i ústavní principy bych na ni v těchto př́padech aplikovala velmi zdrženlivě. Dále lze do této kategorie činností a způsobů užití volné úvahy ochránce zařadit jeho úvahu o tom, zda odložit či nikoli podnět, který neobsahuje veškeré zákonem požadované náležitosti. Ochránci totiž zajisté nelze upírat právo, aby si sám volil, kterými z podnětů bez požadovaných náležitostí se i tak bude zabývat, protože situaci v nich popsanou shledává nápravy hodnou. V těchto př́padech by měl být dostačující zákonný požadavek na písemné odůvodnění odložení podnětu.

Druhou kategorii činností ochránce potom budou tvořit případy užití volné úvahy při volbě způsobu šetření, komunikace se šetřeným a navrhování opatření k nápravě. Jelikož zde, jak již bylo naznačeno, ochránce vystupuje spíše v pozici autoritativní a ve vztahu 
k šetřeným soukromým subjektům dokonce, dá se říci, do určité míry „,vrchnostenské“ “55, mělo by v těchto situacích být uplatňováno více kritérií na jeho činnost než v předchozí kategorii. Ústavní principy by zde měly být uplatňovány důsledněji a žrejmě lze uvažovat i o uplatnění principů dobré správy a základních zásad činnosti správních orgánů, jelikož ve vztahu k soukromým osobám se může činnost ochránce do jisté míry podobat výkonu veřejné moci.

Do kategorie třetí spadá zveřejňování zpráv ochránce v těch př́ipadech, kdy nabývá charakteru sankce. Zde by dle mého názoru ochránce měl při úvaze, zda případ medializuje či nikoli, důsledně uplatňovat nejen principy ústavní, dobré správy a základní zásady činnosti správních orgánů, ale je otázkou, zda by neměl užít i principů správního trestání.

Lze uzavřít, že by mělo být $\mathrm{v}$ nejvlastnějším zájmu ochránce dodržování uvedených kritérií, vzhledem k tomu, že jeho závěry a výstupy jsou z hlediska práva nevynutitelné a jsou prosazovány svou přesvědčivostí. Právě nemožnost vynucení závěru ochránce by tak v tomto kontextu mohla sloužit jako stimul k vysoké kvalitě jeho činnosti.

\section{Přezkum dodržování pravidel vztahujících se na činnost ochránce}

Pro užití správního uvážení či diskrece správním orgánem platí, že je ve většině př́ipadů přezkoumatelné správním orgánem vyššího stupně nebo soudem. Je tedy běžné, že správnost tohoto užití posuzuje několik různých orgánů. Lze dokonce říci, že tento přezkum je jedním z mechanismů, které zabraňují libovůli správního orgánu. Ohledně volné úvahy ochránce se ovšem na první pohled jeví, že přezkum jejího užití je zcela vyloučen. Jsem nicméně toho názoru, že jisté možnosti v tomto směru existují.

Orgán vyššího stupně $\mathrm{v}$ prrípadě ochránce samozřejmě neexistuje, je však nutné mít na paměti, že ochránce je ustanovován Poslaneckou sněmovnou, které za výkon své působnosti odpovídá a pravidelně jí o něm také podává zprávu, kterou má Sněmovna projednat. Je tedy žrejmé, že Sněmovna jistým způsobem činnost ochránce kontroluje, přičemž do rozsahu této kontroly může spadat i to, jestli jeho činnost splnuuje určitá kritéria. Otázkou ovšem zůstává, jestli tato kontrola může dosáhnout nějakých faktických výsledků. Česká právní úprava neumožňuje odvolání ochránce z důvodu nespokojenosti s výkonem jeho funkce, což je ostatně jeden z institutů, který má zajistit jeho nezávislost a nestrannost. $V$ úvahu ovšem připadá to, že jej Sněmovna opětovně nezvolí do funkce, a to at' pro bezprostředně následující funkční období nebo kdykoli v budoucnosti.

Jelikož ochránce prosazuje své názory z pozice morální autority, mohou na něj také výtky Sněmovny ohledně kvality výkonu jeho funkce zapůsobit natolik, že svou činnost sám od sebe

55 Zde lze odkázat na výrok Nejvyššího soudu citovaný na počátku druhé kapitoly - „rozhoduje o tom, zda je třeba v zájmu téchto osob [osob, jejichž zájmy chrání - pozn. aut.] využit kompetence, které mu svěruje zákon, či zda k. tomu diovod není. V závèru z šetreni verejnébo ochránce práv se pak vĩle subjektů, které jsou predmètem tohoto setreni, nemüze promitnout". 
změní kvưli obavě ze snížení svého morálního kreditu. Obdobně na něj zř̌jmě bude působit kontrola ze strany veřejnosti a jeho vlastní sebereflexe, kterou proto lze považovat za nejdůležitější mechanismus přezkumu toho, jak ochránce dodržuje pravidla vztahující se na jeho činnost, protože je v jeho nejvlastnějším zájmu, aby byl veřejností vnímán pozitivně.

Co se soudního přezkumu týče, činnost ochránce mu zásadně nepodléhá. ${ }^{56}$ Objevuje se nicméně judikatura k otázce odpovědnosti státu za škodu způsobenou nesprávným úředním postupem ochránce. ${ }^{57}$ Nedávný citovaný rozsudek Nejvyššího soudu ${ }^{58}$ jednoznačně prohlásil, že ochránce se může dopustit nesprávného úředního postupu a stát následně odpovídat za škodu či újmu ochráncem způsobenou. Tento rozsudek tak podle mého názoru implikuje, že soud (a předtím, v rámci předběžného projednávání nároku, Ministerstvo financî) je oprávněn v rámci řízení o náhradu škody či újmy způsobené ochráncem přezkoumávat správnost jeho postupu i způsob užití jeho volné úvahy.

Toto lze srovnat s judikaturou Soudního dvora Evropské unie, kdy tento ve věci Lamberts $^{59}$ uvedl, že ačkoliv Evropský veřejný ochránce práv má při uplatňování svých pravomocí širokou míru uvážení a zároveň nemá stanoveny konkrétní výsledky, kterých by musel dosáhnout, není soudní přezkum jeho jednání (v rámci řízení ohledně jeho odpovědnosti za škodu) úplně vyloučen. Ve věci Staelen ${ }^{60}$ pak explicitně prohlásil, že Evropský veřejný ochránce práv se může dopustit porušení zásady řádné péče nebo nevyřídit věc $v$ přiměřené lhůtě, tj. že i na něj dopadají povinnosti stanovené v čl. 41 Listiny základních práv Evropské unie. Z tohoto vyplývá nejen to, že Soudní dvůr považuje za povinnosti ochránce dodržovat zásadu řádné péče a vyřizovat věci v přiměřené lhưtě, ale také, že je oprávněn přezkoumávat dodržování těchto povinností a tím také i úvahu ochránce, jaký konkrétní prostředek řešení případu použije a kdy. Toto lze považovat za limitaci užití volné úvahy Evropského veřejného ochránce práv. ${ }^{61}$

56 Jednoznačnou výjimku tvoři rozhodování ochránce (resp. Kanceláre veřejného ochránce práv) o poskytování informací dle zákona č. 106/1999 Sb., o svobodném prístupu k informacím, ve znění pozdějších předpisư; viz závěr kapitoly 1 Možnosti užití volné úvahy ocbránce.

57 Dle zákona č. 82/1998 Sb., o odpovědnosti za škodu způsobenou při výkonu veřejné moci rozhodnutím nebo nesprávným úředním postupem a o změně zákona České národní rady č. 358/1992 Sb., o notárích a jejich činnosti (notářský řád), ve znění pozděǰ̌ích předpisů.

58 Rozsudek Nejvyššího soudu ze dne 27. 9. 2016, sp. zn. 30 Cdo 4118/2015. Závěry z tohoto rozsudku poté byly potvrzeny v rozsudku Nejvyššího soudu ze dne 9. 5. 2018, sp. zn. 30 Cdo 5848/2016.

59 Rozsudek Soudu prvního stupně ze dne 10. 4. 2002, Frank Lamberts vs. Evropské verégný ochránce práv a Evropský parlament, věc T-209/00.

60 Rozsudek Tribunálu ze dne 29. 4. 2015, Claire Staelen vs. Evropský veřéný ocbránce práv, věc. T-217/11 ve spojení s rozsudkem Soudního dvora ze dne 4. 4. 2017, Evropský verégný ochránce práv vs. Claire Staelen, věc $\mathrm{C}-337 / 15 \mathrm{P}$.

61 VOGIATZIS, Nikos. The EU's liability owing to the conduct of the European Ombudsman revisited: European Ombudsman v. Staelen. Common Market Law Review [online]. 2018, roč. 55, č. 4, s. 1267 [cit. 31. 12. 2018]. ISSN 0165-0750. Dostupné z: https://www.kluwerlawonline.com/abstract. php?area $=$ Journals\&id $=$ COLA2018098 
S vědomím zásadních odlišností mezi kontinentálním a anglosaským právním systémem lze také v této souvislosti poznamenat, že před cca třiceti lety byl ve Velké Británii připuštěn soudní přezkum činnosti ombudsmanské instituce $\mathrm{v}$ př́padě, že bude jednat ultra vires, a později byla její zpráva prohlášena za nicotnou, jelikož její závěry byly zcela vadné. ${ }^{62}$ Následně byl před přbližně 20 lety soudem anulován závěr Parlamentního komisaře o tom, že došlo ke špatné správě, s tím, že závěr Komisaře byl nedostatečně odůvodněn. ${ }^{63} \mathrm{~V}$ současné době není ve Velké Británii zpochybňováno, že je možné přezkoumat činnost ombudsmanské instituce soudně, soudy však přihlíží k tomu, že má širokou míru volného uvážení. ${ }^{64}$ Soudní kontrola její činnosti se tak z hlediska stěžovatelů (resp. žalobců) napadajících tuto činnost v praxi neukazuje jako prŕliš efektivní. ${ }^{65}$

\section{Závěr}

Činnost veřejného ochránce práv je rozmanitá a je jedním z charakteristických rysů této instituce, že je při ní ochránce nadán velkou mírou volné úvahy, jaké prostředky použije k plnění svých úkolı̊ a zda vưbec nějaké prostředky použije. Nicméně je otázkou, zda je prri své činnosti a využívání této volné úvahy ochránce nějak limitován. V některých př́padech může jeho činnost nabývat více či méně charakteru veřejné správy a užití jeho volné úvahy se tak může začít podobat uplatňování správního uvážení. Toto je nejvýraznější v situacích, kdy ochránce provádí svou kontrolní činnost, zejména vưči soukromým subjektům, a zveřejňování svých zpráv v těch př́ípadech, kdy nabývají charakteru sankce.

Zákon o veřejném ochránci práv a ani jiné zákony ochránci z logiky věci prriliš mnoho pravidel nestanovují. Přesto však lze českou právní úpravu v tomto směru považovat za ne zcela ideální, jelikož pravidla jí stanovená nejsou vždy jednoznačná a úplná. Ani ochránce sám většinou veřejně neuvádí, jaká pravidla si pro svou vlastní činnost stanovuje. Je tak poměrně obtížné odhadnout, čím se vlastně ochránce při své činnosti rrídí a čím se cítí být vázán.

Když odhlédneme od kritérií etických a morálních, která by se na činnost ochránce jako orgánu stavícího na své morální autoritě jistě vztahovat měla, zbývá otázka vztažení právních zásad a principů na jeho činnost. Nelze pochybovat o tom, že na jeho činnost se vztahují principy ústavní. V úvahu připadají i principy dobré správy a základní zásady činnosti správních orgánů, a to v těch případech, kdy činnost ochránce částečně nabývá charakteru výkonu veřejné moci. Sporným by mohlo být, zda lze na ochráncovu úvahu,

62 Oba tyto případy se týkaly Komisařů pro místní samosprávu.

63 BARNETT, Hilaire. Constitutional\&administrative law. 6. vyd. Oxon: Routledge-Cavendish, 2006, s. 816. ISBN 1-84568-033-2.

64 KIRKHAM, Richard. Judicial review, litigation effects and the ombudsman. Journal of Social Welfare and Family Law [online]. 2018, č. 1, s. 110-125 [cit. 10. 4. 2018]. Dostupné z: https://www.tandfonline.com/ doi/full /10.1080/09649069.2017.1415244

65 Ibid. 
zda medializovat určité př́pady, aplikovat i principy správního trestání; za současného stavu však lze říci, že zřejmě nikoli.

Oproti užití správního uvážení, které je široce přezkoumatelné množstvím orgánů, je přezkum užití volné úvahy ochránce silně omezen. Základem v tomto směru je jeho vlastní sebereflexe a kontrola ze strany veřejnosti, která slouží i jako vodítko pro další sebereflexi ochránce, protože je v jeho nejvlastnějším zájmu, aby byl veřejností vnímán pozitivně a přesvědčivě. Jistou roli může v tomto směru hrát i přezkum jeho činnosti Poslaneckou sněmovnou, které za výkon své působnosti odpovídá. V poslední době se také ukazuje, že velmi omezený přezkum činnosti ochránce a užití jeho volné úvahy může být vykonáván i soudně $\mathrm{v}$ případě uplatnění nároku proti státu ohledně postupu ochránce dle zákona o odpovědnosti státu za škodu. 